\title{
Jewish Religion after \\ Theology
}


EMUNOT: Jewish Philosophy and Kabbalah

$$
\text { Dov Schwartz (Bar-Ilan University), }
$$

Series Editor

\author{
Editorial board \\ Ada Rapoport-Albert (University College, London) \\ Gad Freudenthal (C.N.R.S, Paris) \\ Gideon Freudenthal (Tel Aviv University) \\ Moshe Idel (Hebrew University, Jerusalem) \\ Raphael Jospe (Bar-Ilan University) \\ Ephraim Kanarfogel (Yeshiva University) \\ Menachem Kellner (Haifa University) \\ Daniel Lasker (Ben-Gurion University, Beer Sheva)
}

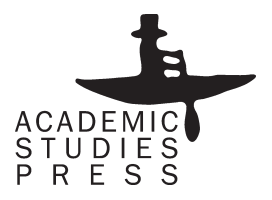




\section{JEWISH RELIGION after THEOLOGY}

Avi Sagi

Translated by Batya Stein 
Copyright (C) 2009 Academic Studies Press

All rights reserved

ISBN 978-1-934843-56-7

Book design by Olga Grabovsky

Published by Academic Studies Press in 2009

28 Montfern Avenue

Brighton, MA 02135, USA

press@academicstudiespress.com

www.academicstudiespress.com

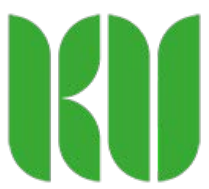

An electronic version of this book is freely available, thanks to the support of libraries working with Knowledge Unlatched. KU is a collaborative initiative designed to make high quality books Open Access for the public good. The Open Access ISBN for this book is 978-1-644-69330-8. More information about the initiative and links to the Open Access version can be found at www.knowledgeunlatched.org.

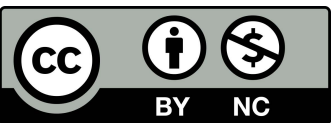

Effective March 20, 2020, this book is subject to a CC-BY-NC license. To view a copy of this license, visit https://creativecommons.org/licenses/by-nc/4.0/. Other than as provided by these licenses, no part of this book may be reproduced, transmitted, or displayed by any electronic or mechanical means without permission from the publisher or as permitted by law. 